\title{
Preliminary Phyto-pharmacological Investigation of Duabanga Grandiflora (Roxb. ex DC.) Walpers
}

\author{
Sanjida Sharmin ${ }^{1}$, Tahmina Sifat ${ }^{1}$, Afrina Azad ${ }^{2}$, A. S. M. Ali Reza ${ }^{1,3}$, Mohammad \\ Kaisarul Islam $^{4}$ and Mohammed Abu Sayeed ${ }^{1}$ \\ ${ }^{1}$ Department of Pharmacy, International Islamic University Chittagong, Chittagong-4318, Bangladesh \\ ${ }^{2}$ Bangladesh Council of Scientific and Industrial and Research (BCSIR), Dhaka-1205 \\ ${ }^{3}$ Department of Biochemistry and Molecular Biology, University of Chittagong, Chittagong \\ ${ }^{4}$ Phytochenical Research Laboratory, Department of Pharmaceutical Chemistry \\ University of Dhaka, Dhaka-1000, Bangladesh
}

(Received: January 22, 2020; Accepted: January 28, 2020; Published: January 30, 2020)

\begin{abstract}
The methanolic extract of Duabanga grandiflora (Roxb. ex DC.) Walpers leaves was investigated to explore in-vitro anti-arthritic, thrombolytic and antioxidant potential and subsequent detection of preliminary phytochemicals. It is used for treating various diseases by folk practitioners and rural people. Initially, BSA protein denaturation method was employed to evaluate in-vitro anti-arthritic potency, where the extract exhibited potent anti-arthritic activity with $73.52 \pm 1.01 \%$ inhibition of BSA denaturation at a dose of $1000 \mu \mathrm{g} / \mathrm{ml}$ compared to the standard dichlofenac sodium $(83.66 \pm 1.03 \%$ inhibition at $1000 \mu \mathrm{g} / \mathrm{ml}$ dose). In-vitro thrombolytic efficacy was determined using streptokinase (positive control) and water (negative control), and the average lysis of blood clot was found to be $31.12 \pm 1.09 \%$, which is indicative towards the thrombolytic effect of the extract. Antioxidant activity was evaluated by the DPPH radical scavenging method followed by the total phenolic and flavonoid content determination. The crude methanolic extract revealed the $\mathrm{IC}_{50}$ value of $129.31 \mu \mathrm{g} / \mathrm{ml}$ and $204.89 \mu \mathrm{g} / \mathrm{ml}$ against DPPH and standard ascorbic acid, respectively. The total phenolic content and total flavonoid content of the plant leaves were observed to be $52.81 \pm 1.74 \mu \mathrm{g} / \mathrm{ml}$ and $25.77 \pm 1.01 \mu \mathrm{g} / \mathrm{ml}$, respectively. The results indicate that the leaves of $D$. grandiflora possess favorable anti-arthritic activity, moderate thrombolytic and excellent antioxidant activity, which is demonstrating the presence of alkaloids, phenols, flavonoids and many other biologically important phyto-constituents that needs further exploration.
\end{abstract}

Key words: Duabanga grandiflora (Roxb. ex DC.) Walpers, protein denaturation assay, anti-arthritic, antioxidant, thrombolytic.

\section{Introduction}

Plants had been used for medicinal purposes long before recorded history. Plants have an enormous prospective for producing novel drugs for human benefit. Plants used in conventional medicine contain an immeasurable collection of substances that can be used to treat chronic and infectious diseases. According to a report of World Health Organization, It has been seen that still now almost $80 \%$ of the world's population depend upon plants for their primary treatment, despite of the advancement in synthetic medicine (Duraipandiyan et al., 2006). Around $25 \%$ of available medicines are derivatives of either plant's primary or secondary metabolites. As the plant kingdom possesses a considerable level of variety in their biological and chemical nature, it is expected that plants could be a promising sources of the novel compounds to fight against various

Correspondence to: Sanjida Sharmin; Phone: +8801674883783; E-mail: sharmin.shanjida@ gmail.com

DOI: https://doi.org/10.3329/bpj.v23i1.45320 
ailments. Furthermore, current developments in the field of molecular biology and plant biotechnology added additional dimensions to the application of plants in the preparation of medicinal agents (Ansari et al., 2017; Fowler et al., 2006). Hence, there are requirements to screen medicinal plants for potential biological activity.

Arthritis is a chronic inflammatory disorder that affects the person's joints and muscles surrounding the joints. Just like other autoimmune disorder, it causes production of autoantibody that affects bone and cartilage of the joints associated with hyperplasia and synovial inflammation. There are more than hundreds different types of arthritis, having almost identical sign and symptoms but different reasons of their causes. The most common symptom of this disease includes sore, stiffness, swelling, inflammation and pain of the joints (Majithia et al., 2007; Hossain et al., 2018; Singh et al., 2010). This condition is commonly treated with non-steroidal anti-inflammatory drugs or anti-rheumatic agents. Traditionally, plant extracts were used for relieving arthritic pain.

Thrombosis is the formation of clots (thrombus) and blockage of blood vessels. The deep vein thrombosis is fatal and it can lead to death due to ischemic stroke and acute myocardial infarction. The only medicine available other than surgical interventions is the intravenous administration of different thrombolytic agents (such as streptokinase) to dissolve the clot within the blood vessel (Kunamneni et al., 2007; Mobarak et al., 2018). Most of the available thrombolytic agents have verities of shortcomings. For this reason, attempts are ongoing to originate improved alternative of these medicines (Sumi et al., 1990; Furie et al., 2008).

An antioxidant is any substance that prevents the oxidation of other substances. The free radicals originated from the oxidation reactions can initiate chain reactions. When this sort of chain reaction happens in a living cell, it causes destruction or death to that cell. Antioxidants remove the free radicals and inhibit the chain reactions as well as suppress other oxidation reactions (Reza et al., 2018). They are being actually oxidized themselves and prevent oxidation of other molecules exactly what reducing agents do. For this reason, reducing agents often act as antioxidants. Such examples of antioxidants include ascorbic acid, thiols or polyphenols. Superoxide dismutase, catalase-peroxidase are examples of several enzymes having a radical scavenging effect. Different types of phytochemicals like phenols, flavonoids, carotenoids, fatty acids, tocopherol, and alkaloids also have antioxidant action and protect the organism from oxidative degradation. Antioxidants lower the risk of heart disease, muscle degeneration, some neurological diseases, and cancer.

The plant used in the current study, Duabanga grandiflora (Roxb. ex DC.) Walpers (Family: Lythraceae) is an evergreen tree which isable to grow up to about 18 - $30 \mathrm{~m}$ height. Branches tend to spread out horizontally in all directions and drooping from the trunk. This plant is traditionally used in the tribe's areas for the reduction of joint pain, stomach ache, eye inflammation (Azwanida et al., 2015). The D. grandiflora leaf extracts showed dose-dependent antiviral activities through plaque formation and viral replication inhibitions (Malik et al., 2016). Kaweetripob and co-workers reported a number of secondary metabolites which were isolated from the stem bark of D. grandiflora, where several of them have cytotoxic properties cancer cell lines (Kaweetripob et al., 2012). Besides, it has been observed in another study that the leaf extract of $D$. grandiflora possess skin whitening, antiaging, and anti-inflammatory properties on human skin cells (Tsukiyama et al., 2010).

In the present experiment an attempt has been made to evaluate the anti-arthritic efficacy, thrombolytic potential, antioxidant properties of different extracts of $D$. grandiflora. Besides, total phenolic content and flavonoid content as well as presence of possible class of phytochemicals were also assessed to determine the significance of plant. 


\section{Materials and Methods}

Collection of sample and extraction: The leaves of Duabanga grandiflora were collected from the Chittagong hill tract area of Bangladesh in May 2018. It was identified by Dr. Shaikh Bakhtiar Uddin, Professor, Department of Botany, University of Chittagong, Bangladesh.

After the collection and identification, the plant samples (leaves) were cleaned, sun dried and ground and blend into fine powder. For appropriate extraction, $575.21 \mathrm{gm}$ of the powder was soaked for 15 days in 2.5 liters of methanol in a sealed container, which was allowed to manual shaking to facilitate the extraction of phyto-chemicals. The whole content was filtered with the help of filter paper and the Buchner funnel. Finally, the filtrate was evaporated in a hot water bath at $40^{\circ} \mathrm{C}$ to achieve the crude extract (a thick deep green colored extract was found).

Phytochemical analysis: Preliminary qualitative phytochemical analysis was performed for the detection of carbohydrates, alkaloids flavonoids, saponins, glycosides, tannins, protein and phenols in the selected plants part following standard procedures (Harborne et al., 1998).

In-vitro anti-arthritic assay: The anti-arthritic efficacy of $D$. grandiflora was studied by inhibition of bovine serum albumin (BSA) denaturation technique described by Mizushima and co-workers (Govindappa et al., 2011) followed by few modifications. Phosphate buffer saline was prepared by dissolving $0.887 \mathrm{~g}$ of $\mathrm{Na}_{2} \mathrm{HPO}_{4}$ and $0.45 \mathrm{~g}$ of $\mathrm{NaH}_{2} \mathrm{PO}_{4}$ in $100 \mathrm{ml}$ water. Then the $\mathrm{pH}$ was adjusted to 6.3 adding $1 \mathrm{~N} \mathrm{HCl}$ solution. 5\% BSA solution was prepared using distilled water. The test solution was prepared by mixing $0.45 \mathrm{ml}$ of BSA solution and 0.05 $\mathrm{ml}$ of methanolic extract solution of various concentration (500, 250, 125, 62.5, 31.25 $\mu \mathrm{g} / \mathrm{ml})$. The test control solution $(0.5 \mathrm{ml})$ was prepared by mixing $0.45 \mathrm{ml}$ of $0.5 \% \mathrm{w} / \mathrm{v}$ BSA solution and $0.05 \mathrm{ml}$ of distilled water. The product control $(0.5 \mathrm{ml})$ was prepared by mixing $0.45 \mathrm{ml}$ of distilled water and $0.05 \mathrm{ml}$ of test solution. Finally, $0.45 \mathrm{ml}$ of BSA and $0.05 \mathrm{ml}$ of varying concentration of diclofenac sodium was mixed to prepare Standard solution (0.5ml.All the solutions were kept at $37^{\circ} \mathrm{C}$ for 20 minutes. Then the solution was incubated at an elevated temperature of $57^{\circ} \mathrm{C}$ for 3 minutes. Then the solutions were cooled and $2.5 \mathrm{ml}$ of phosphate buffer was mixed in each solution. Using UV-Visible spectrophotometer, the absorbance was recorded at $416 \mathrm{~nm}$ wave length. The inhibition of BSA protein denaturation was expressed in term of percentage and calculated as follows:

$$
\% \text { of inhibition of protein denaturation=100 }-\frac{\text { Abs of Test solution }- \text { Abs of product control }}{\text { Abs of Test control }} \times 100 \%
$$

In-vitro thrombolytic assay: To study in-vitro thrombolytic effect, $5 \mathrm{ml}$ of blood was collected from the ten healthy volunteers having no previous history taking aspirin or any other drug having anticoagulant effect. The blood $(0.5 \mathrm{ml})$ was then distributed to previously weight ten sterile microcentrifuge tubes, which were then incubated at $37^{\circ} \mathrm{C}$ for 45 minutes to form the clot. Afterwards, the supernatant serum was gently removed and weights of each tube (containing clots) were measured to determine clots' weight. Then $100 \mu \mathrm{l}$ of methanolic extract of the plant (concentration $10 \mathrm{mg} / \mathrm{ml}$ ) was added to each tube having clot, where $100 \mu \mathrm{l}$ of streptokinase and $100 \mu \mathrm{l}$ of distilled water were used as positive and negative control, respectively. These tubes were further incubated at $37^{\circ} \mathrm{C}$ for 90 minutes and the released fluid was removed after incubation. Then weights of each tube were measured and the difference in weight was observed after clot disruption. The clot lysis effect was expressed as percentage as follows (Prasad et al., 2006):

$$
\% \text { clot lysis }=\frac{\text { Wight of clot after addition of test solution or standard }}{\text { clot weight }} \times 100
$$


In-vitro antioxidant assay (DPPH assay): The antioxidant effect of the plant extract was evaluated using DPPH (Braca et al., 2001). At first, 0.004\% DPPH (2,2-diphenyl-1-picrylhydrazyl) solution was prepared in $95 \%$ methanol, where methanol was served as reagent as well as control solution. The sample solution $(1 \mathrm{mg} / \mathrm{ml})$ was prepared in methanol, which was further diluted to achieve different concentrations. Standard solution was prepared using ascorbic acid, described in a standard procedure fashion (Pisoschi et al., 2011; Pisoschi et al., 2012) and methanol was used as blank. The test sample and the standard $(0.1 \mathrm{ml})$ of varied concentrations $(15.63$ to $500.00 \mu \mathrm{g} / \mathrm{ml}$ ) were added to DPPH solution ( $3 \mathrm{ml}$ each) containing test tubes and all the mixtures were kept at $25^{\circ} \mathrm{C}$ for $30 \mathrm{~min}$ to complete the reaction. Then the absorbance was recorded at $517 \mathrm{~nm}$ by using UV-visible spectrophotometer. The percentage inhibition was determined as follows:

$$
\% \text { inhibition }=\frac{\text { absorbance of control }- \text { absorbance of the test sample or standard }}{\text { absorbance of control }} \times 100 \%
$$

$\mathrm{IC}_{50}$ values were determined from $\%$ inhibition vs. concentration graph (Kharchouf et al., 2019).

Total amount of phenolic content determination: The total amount of phenolic content of the plant extract was determined by following reported protocol (Skerget et al., 2005) using Folin-Ciocalteu reagent (i.e., a mixture of phosphomolybdate and phosphotungstate) as oxidizing agent and gallic acid as standard. Then the absorbance of the mixture was recorded at $760 \mathrm{~nm}$. The same process was conducted in triplicates. The total content of phenolic compound was calculated using Gallic acid standard curve and therefore the amount were represented as gallic acid equivalent per gm of dried fraction by utilizing the formula:

$$
\mathrm{A}=\frac{\text { Gallic acid's concentration }(\mathrm{mg} / \mathrm{ml}) \times \text { Volume of extract }(\mathrm{ml})}{\text { Weight of plant extract }(\mathrm{gm})}
$$

Total amount of flavonoid content determination:

Total amount of flavonoid content of the methanolic extract was measured by aluminum colorimetric assay (Oyedemi et al., 2011; Sagbo et al., 2017). $1 \mathrm{ml}$ of the test sample $(1 \mathrm{mg} / \mathrm{ml})$ or standard quercetin (at a concentrations ranges from 100 to $12.5 \mu \mathrm{g} / \mathrm{ml}$ ) was mixed with methanol $(3 \mathrm{ml}), 10 \% \mathrm{w} / \mathrm{v}$ aqueous solution of $\mathrm{AlCl}_{3}(0.2 \mathrm{ml}), 1 \mathrm{M}$ potassium acetate $(0.2$ $\mathrm{ml})$ and distilled water $(5.6 \mathrm{ml})$. The mixture was kept at the room temperature for $30 \mathrm{~min}$ to finish the reaction. Then the absorbance was recorded at 420 $\mathrm{nm}$. The whole process was repeated for three times. Quercetin standard curve was used to calculate total amount of flavonoid contents and the results were presented as quercetin equivalent per gm of dried fraction by using the following formula:

$$
\mathrm{A}=\frac{\text { Quercetin's concentration }(\mathrm{mg} / \mathrm{ml}) \times \text { Volume of extract }(\mathrm{ml})}{\text { Weight of plant extract }(\mathrm{gm})}
$$

\section{Result and Discussion}

In this investigation, positive results were found for alkaloids, carbohydrates, flavonoids, tannins, proteins, phenol (Table-1), which are indicative for imparting the pharmacological actions (Mendoza et al., 2018).
The in-vitro studies on leaves on D. grandiflora indicate the presence of significant anti-arthritic potency. The extract showed the maximum of $73.52 \pm 1.01 \%$ inhibition, at a dose of $1000 \mu \mathrm{g} / \mathrm{ml}$, where the standard dichlofenac sodium exhibited $83.66 \pm 1.03 \%$ inhibition at the same dose (Table-2). 
In the thrombolytic (in-vitro) study, $D$. grandiflora leaves led to $31.12 \pm 1.09 \%$ clot lysis, where as the commonly used drug streptokinase (100 $\mu \mathrm{l}$ of $15,00,000$ I.U.) resulted in $75 \pm 1.15 \%$ clot lysis, and distilled water exhibited very negligible lysis of clot $(4.84 \pm 1.11 \%)$ (Table 3). Plant metabolites, specially glycosides and flavonoids, interfere with the function of platelets and exert thrombolytic effect (Kim et al., 2008; Tabassum et al., 2017).

Table 1. Initial Phytochemical screening of $D$. grandiflora leaves.

\begin{tabular}{llllll}
\hline Group Test & Test's Name & Observation & Group Test & Test's Name & Observation \\
\hline Alkaloids & Meyer's Test & ++ & Glycosides & Acetic Acid test & + \\
& Wagner's Test & ++ & & & \\
Carbohydrates & Molish's Test & + & Proteins & BSA Test & + \\
& Benedict's Test & - & & & ++ \\
Flavonoids & Hydrochloric Acid Test & ++ & Phenolic Compound & $\mathrm{FeCl}_{3}$ Test & + \\
Saponins & Foam Test & - & Tannins & $\mathrm{Pb}(\mathrm{OAc})_{2}$ Test & + \\
\hline
\end{tabular}

$(++)=$ Rapidly present, $(+)=$ Present,$(-)=$ Absent

Table 2. Anti-arthritic activity of $\boldsymbol{D}$. grandiflora leaves extract and standard (diclofenac sodium).

\begin{tabular}{cccc}
\hline \multicolumn{2}{c}{ Sample } & & \multicolumn{2}{c}{ Standard } \\
\hline Concentration $(\mu \mathrm{g} / \mathrm{ml})$ & $\%$ inhibition & Concentration $(\mu \mathrm{g} / \mathrm{ml})$ & $\%$ inhibition \\
1000 & $73.53 \pm 1.01$ & 1000 & $85.67 \pm 1.03$ \\
500 & $61.76 \pm 1.08$ & 500 & $83.67 \pm 1.12$ \\
250 & $55.88 \pm 1.01$ & 250 & $71.33 \pm 1.05$ \\
125 & $38.24 \pm 1.07$ & 125 & $54.67 \pm 1.17$ \\
62.5 & $14.71 \pm 1.13$ & 62.5 & $44.33 \pm 1.11$ \\
31.5 & $8.82 \pm 1.12$ & 31.5 & $38 \pm 1.01$ \\
\hline
\end{tabular}

Table 3. Clot lysis by water and $D$. grandiflora compared with streptokinase.

\begin{tabular}{lc}
\hline Group & $\%$ of clot lysis \\
\hline Streptokinase & $75 \pm 1.15$ \\
Water & $4.84 \pm 1.11$ \\
Duabanga grandiflora & $31.12 \pm 1.09$ \\
\hline
\end{tabular}

The extract showed a dose-dependent radical scavenging result in the DPPH assay. The inhibition concentration $\left(\mathrm{IC}_{50}\right)$ for complimentary radicals achieved by the extract was $129.31 \mu \mathrm{g} / \mathrm{ml}$ that is statistically vital compared thereto $\mathrm{IC}_{50} 204.89 \mu \mathrm{g} / \mathrm{ml}$ of water-soluble vitamin ascorbic acid that is shown in the table 4.
Table 4. DPPH radical scavenging for $D$. grandiflora leaves and standard ascorbic acid.

\begin{tabular}{ccc}
\hline \multirow{2}{*}{$\begin{array}{c}\text { Concentration } \\
(\mu \mathrm{g} / \mathrm{ml})\end{array}$} & \multicolumn{2}{c}{$\%$ of scavenging } \\
\cline { 2 - 3 } 500 & Sample & Standard \\
250 & $67.33 \pm 1.04$ & $68.67 \pm 1.02$ \\
125 & $58.83 \pm 1.15$ & $52.73 \pm 1.07$ \\
62.5 & $40.71 \pm 1.19$ & $39.25 \pm 1.04$ \\
31.25 & $37.34 \pm 1.01$ & $35.79 \pm 1.01$ \\
15.625 & $35.15 \pm 1.02$ & $28.87 \pm 1.17$ \\
\hline
\end{tabular}

In the present investigation, the total amount of phenolic content of $D$. grandiflora leaves was calculated from the calibration curve $\left(\mathrm{R}^{2}=0.9693\right)$, was found to be $52.81 \pm 1.74 \mathrm{GAE} / \mathrm{gm}(\mathrm{GAE}=$ gallic acid equivalent), and the total amount of flavonoid 
content was calculated from the calibration curve of quercetin $\left(\mathrm{R}^{2}=0.9693\right)$ and it was determined to be $29.77 \pm 1.01 \mathrm{QE} / \mathrm{gm}(\mathrm{QE}=$ quercetin equivalent $)$. Phenol and flavonoids are the most important plant constituents having scavenging ability. Therefore, phenolic compounds and flavonoids may have a direct influence on the antioxidant action in this study (Liaudanskas et al., 2017).

\section{Conclusion}

This well-informed study evaluated the presence of significant phytochemicals as well as anti-arthritic, thrombolytic and anti-oxidant activities of Duabanga grandiflora leaves. The investigation revealed that the plant possesses moderate anti-arthritic activity, mild clot lysis activity and significant antioxidant activity. From the findings, it is suggested that this plant may be a favourable source for the isolation of potent herbal drugs and pain-reducing agents. Therefore, precise studies are needed to separate the active phytochemicals responsible for bioactivity and to elucidate the mechanism of their action, if possible.

\section{Acknowledgements}

The authors are grateful to the Department of Pharmacy, International Islamic University Chittagong (IIUC), Bangladesh, for providing the facilities to perform this research work smoothly.

\section{References}

Ansari, P., Uddin, M.J., Rahman, M.M., Abdullah-AlMamun, M., Islam, M.R., Ali, M.H. and Reza, A.A. 2017. Anti-inflammatory, anti-diarrheal, thrombolytic and cytotoxic activities of an ornamental medicinal plant: Persicaria orientalis. J. Basic Clin. Physiol. Pharmacol. 28, 51-58.

Azwanida, N.N. 2015. A review on the extraction methods use in medicinal plants, principle, strength and limitation. Med. Aromat. Plants. 4, 196.

Braca, A., De Tommasi, N., Di Bari, L., Pizza, C., Politi, M. and Morelli, I. 2001. Antioxidant principles from Bauhinia tarapotensis. J. Nat. Prod. 64, 892-895.

Duraipandiyan, V., Ayyanar, M. and Ignacimuthu, S. 2006. BMC Comp. Alter. Med. 6, 35-41.
Fowler, M.W. 2006. Plants, medicines and man. J. Sci. Food Agric. 86, 1797-1804.

Furie, B. and Furie, B.C. 2008. Mechanisms of thrombus formation. New Engl. J. Med. 359, 938-949.

Govindappa M., Naga Sravya S., Poojashri M.N., Sadananda T.S. and Chandrappa C.P. 2011. Antimicrobial, antioxidant and in vitro antiinflammatory activity of ethanol extract and active phytochemical screening of Wedelia trilobata (L.) Hitchc. J. Pharmacognosy Phytother. 3, 43-51.

Harborne, A. 1998. Phytochemical methods a guide to modern techniques of plant analysis. Springer Science $\&$ Business Media, Springer Netherlands.

Hossain, M.S., Reza, A.A., Rahaman, M.M., Nasrin, M.S., Rahat, M.R.U., Islam, M.R., Uddin, M.J. and Rahman, M.A. 2018. Evaluation of morning glory (Jacquemontia tamnifolia (L.) Griseb) leaves for antioxidant, antinociceptive, anticoagulant and cytotoxic activities. J Basic Clin. Physiol. Pharmacol. 29, 291-299.

Kaweetripob, W., Mahidol, C., Prachyawarakorn, V., Prawat, H. and Ruchirawat, S. 2012. 5-formylfurfuryl esters from Duabanga grandiflora. Phytochemistry. 76, 78-82.

Kharchouf, S., Bouchador, A., Drioiche, A., Khiya, Z., El Hilali, F. and Zair, T.J.P., 2019. Phytochemistry and antioxydante activity of Stevia rebaudiana. Pharmacognosie. 17, 90-96.

Kim, J.M. and Yun-Choi, H.S., 2008. Anti-platelet effects of flavonoids and flavonoid-glycosides from Sophora japonica. Arch. Pharmacal Res. 31, 886.

Kunamneni, A., Abdelghani, T.T. and Ellaiah, P. 2007. Streptokinase - the drug of choice for thrombolytic therapy. J. Thromb. Thrombolysis. 23, 9-23.

Liaudanskas, M., Zymonè, K., Viškelis, J., Klevinskas, A. and Janulis, V. 2017. Determination of the phenolic composition and antioxidant activity of pear extracts. J. Chem. 2017, 1-9.

Majithia, V. and Geraci, S.A. 2007. Rheumatoid arthritis: diagnosis and management. Am. J. Med. 120, 936-939.

Malik, F.Z.A., Allaudin, Z.N., Loh, H.S., Nee, T.K., Hani, H. and Abdullah, R. 2016. Antiviral and virucidal activities of Duabanga grandiflora leaf extract against Pseudorabies virus in vitro. BMC Complement. Altern. Med. 16, 139.

Mendoza, N. and Silva, E.M.E., 2018. Introduction to phytochemicals: secondary metabolites from plants with active principles for pharmacological importance. Phytochemicals: source of antioxidants and role in disease prevention, Intech. Open. 25. 
Mobarak, H., Meah, M.S., Sikder, N., Tareq, M., Azad, A., Khatun, R., Nasrin, M.S., Raihan, M.O. and Reza, A.A. 2018. Investigation of preliminary phytochemicals, analgesic, anti-arthritic, thrombolytic and cytotoxic activities of Begonia roxburghii (Miq.) DC. leaves. Med. One. 3, 1-12.

Oyedemi, S.O. and Afolayan, A.J. 2011. Antibacterial and antioxidant activities of hydroalcoholic stem bark extract of Schotia latifolia Jacq. Asian Pac. J. Trop. Med. 4, 952-958.

Pisoschi, A.M. and Negulescu, G.P. 2012. Methods for total antioxidant activity determination: a review. Biochem. \& Anal. Biochem. 1, 106.

Pisoschi, A.M., Pop, A., Negulescu, G.P. and Pisoschi, A. 2011. Determination of ascorbic acid content of some fruit juices and wine by voltammetry performed at $\mathrm{Pt}$ and carbon paste electrodes. Molecules. 16, 13491365 .

Prasad, S., Kashyap, R.S., Deopujari, J.Y., Purohit, H.J., Taori, G.M. and Daginawala, H. 2006. Development of an in vitro model to study clot lysis activity of thrombolytic drugs. Thromb. J. 4, 14.

Reza, A.A., Hossain, M.S., Akhter, S., Rahman, M.R., Nasrin, M.S., Uddin, M.J., Sadik, G. and Alam, A.K., 2018. In vitro antioxidant and cholinesterase inhibitory activities of Elatostema papillosum leaves and correlation with their phytochemical profiles: a study relevant to the treatment of Alzheimer's disease. BMC Complement. Altern. Med. 18, 123.
Sagbo, I.J., Afolayan, A.J. and Bradley, G.J. 2017. Antioxidant, antibacterial and phytochemical properties of two medicinal plants against the wound infecting bacteria. Asian Pac. J. Trop. Biomed. 7, 817-825.

Singh, S., Kumar, A., Panneerselvam, K. and Vennila, J.J. 2010. Diagnosis of arthritis through fuzzy inference system. J. Med. Syst. 36, 1459-1468.

Skerget, M., Kotnik, P., Hadolin, M., Hras, A.R., Simonic, M. and Knez, Z. 2005. Phenols, proanthocyanidins, flavones and flavonols in some plant materials and their antioxidant activities. Food Chem. 89, 191-198.

Sumi, H., Hamada, H., Nakanishi, K. and Hiratani, H. 1990. Enhancement of the fibrinolytic activity in plasma by oral administration of nattokinases. Acta Haematol. 84, 139-143.

Tabassum, F., Chandi, S.H., Mou, K.N., Hasif, K.I., Ahamed, T. and Akter, M., 2017. In vitro thrombolytic activity and phytochemical evaluation of leaf extracts of four medicinal plants of Asteraceae family. $J$. Pharmacogn. Phytochem. 6, 1166-1169.

Tsukiyama, M., Sugita, T., Kikuchi, H., Yasuda, Y., Arashima, M., Okumura, H., Lhieochaiphant, S. and Shoyama, Y. 2010. Effect of Duabanga grandiflora for human skin cells. Am. J. Chinese Medi. 38, 387399. 